(c) Inra/Elsevier, Paris

\title{
Selection for reduced muscle glycolytic potential in Large White pigs. II. Correlated responses in meat quality and muscle compositional traits
}

\author{
Catherine Larzul ${ }^{\mathrm{a} *}$, Pascale Le Roy ${ }^{\mathrm{a}}$, Jean Gogué ${ }^{\mathrm{b}}$,
} André Talmant ${ }^{c}$, Bernard Jacquet ${ }^{\mathrm{d}}$, Louis Lefaucheur ${ }^{\mathrm{e}}$, Patrick Ecolan ${ }^{\mathrm{e}}$, Pierre Sellier ${ }^{\mathrm{a}}$, Gabriel Monin ${ }^{\mathrm{c}}$

${ }^{a}$ Station de génétique quantitative et appliquée, Institut national de la recherche agronomique, 78352 Jouy-en-Josas cedex, France

b Institut national de la recherche agronomique, domaine de Galle, 18520 Avord, France

c Station de recherches sur la viande, Institut national de la recherche agronomique, Theix, 63122 St-Genès-Champanelle, France

${ }^{\mathrm{d}}$ Centre technique de la salaison, de la charcuterie et des conserves de viandes, 94704 Maisons-Alfort cedex, France

e Station de recherches porcines, Institut national de la recherche agronomique, 35590 L'Hermitage, France

(Received 3 March 1998; accepted 19 November 1998)

\begin{abstract}
A selection experiment was conducted over six generations in a purebred French Large White population presumably free of the $\mathrm{HAL}^{\mathrm{n}}$ and $\mathrm{RN}^{-}$alleles. Two lines were taken from the same base population and were contemporarily bred: one control line (C) and one line (S) selected for reduced in vivo glycolytic potential (IVGP) of the longissimus muscle. Throughout the experiment, second-parity animals were slaughtered at $100 \mathrm{~kg}$ body weight in order to evaluate the correlated effects of selection on meat quality and muscle compositional traits. Heritability values, genetic correlations with the selection criterion and average genetic trends per generation were estimated for all traits. Heritability values for the traits measured on several muscles depended on the muscle. Within muscle heritability, estimates for ultimate $\mathrm{pH}$ and lightness $\mathrm{L}^{*}$ value were of the same order. For enzyme activities, estimates of heritability were from 0.12 to 0.44 for lactate dehydrogenase (LDH), from 0.22
\end{abstract}

* Correspondence and reprints

Present address: Station d'amélioration génétique des animaux, centre Inra de Toulouse, B.P. 27, 31326 Castanet-Tolosan cedex, France

E-mail: larzul@toulouse.inra.fr 
to 0.44 for citrate synthase (CS) and from 0.06 to 0.26 for the LDH/CS ratio. Heritability values for longissimus muscle compositional traits were of medium range (from 0.33 to 0.59 ), except for nitrogen content. The heritability estimate for the technological yield of cured-cook ham processing was $0.32 \pm 0.09$. Most physiological and chemical characteristics of the longissimus muscle were not significantly affected by selection. No genetic change was found for technological yield, though the genetic correlation of this trait with IVGP was in the medium range $(-0.42 \pm 0.12)$. The $\mathrm{S}$ line showed significant genetic trends for longissimus muscle enzyme activities and fibre characteristics, indicating that it had a more glycolytic muscle metabolism than the $\mathrm{C}$ line, with a lower proportion of oxido-glycolytic fibres, a higher proportion of glycolytic fibres, a higher LDH/CS ratio and a lower haem pigment content. (C) Inra/Elsevier, Paris

pig / selection experiment / glycolytic potential / muscle / meat quality

Résumé - Sélection pour un abaissement du potentiel glycolytique du muscle chez le porc Large White. II. Réponses corrélatives pour la qualité de la viande et la composition du muscle. Une expérience de sélection a été conduite sur six générations dans une population de porcs de race pure Large White français, présumée indemne des allèles $\mathrm{HAL}^{n}$ et $\mathrm{RN}^{-}$. Deux lignées ont été formées à partir de la même population de base, et ont été conduites de manière contemporaine : une lignée témoin (C) et une lignée sélectionnée (S) pour diminuer le potentiel glycolytique mesuré in vivo (IVGP) sur le muscle longissimus. Au cours de cette expérience, des animaux issus des deuxièmes portées ont été abattus à $100 \mathrm{~kg}$ de poids vif afin d'étudier les effets de la sélection sur la qualité de la viande et les caractères de composition du muscle. Pour tous les caractères, les valeurs d'héritabilité, les corrélations génétiques avec IVGP et les réponses génétiques moyennes par génération ont été estimées. Pour les caractères mesurés sur plusieurs muscles différents, les valeurs d'héritabilité varient d'un muscle à l'autre. Pour un même muscle, les héritabilités du pH ultime et de la valeur de luminosité $\mathrm{L}^{*}$ sont du même ordre de grandeur. Les héritabilités des activités enzymatiques varient selon le muscle de 0,12 à 0,44 pour la lactate déshydrogénase $(\mathrm{LDH})$, de 0,22 à 0,44 pour la citrate synthase (CS) et de 0,06 à 0,26 pour le rapport $\mathrm{LDH} / \mathrm{CS}$. Les héritabilités estimées pour la composition chimique du muscle longissimus sont moyennes $(0,33$ à 0,59$)$, excepté pour la teneur en azote. L'héritabilité du rendement technologique de la fabrication du jambon cuit est de $0,32 \pm 0,09$. La plupart des caractéristiques physiologiques et chimiques du muscle longissimus ont peu évolué sous l'effet de la sélection. Il en a été de même pour le rendement technologique, bien que la corrélation génétique estimée entre ce caractère et IVGP soit de valeur moyenne $(-0,42 \pm 0,12)$. De plus, la lignée $\mathrm{S}$ a montré une réponse génétique significative pour les activités enzymatiques et pour la typologie des fibres du muscle longissimus. Les animaux de la lignée $\mathrm{S}$ avaient un métabolisme musculaire plus glycolytique que ceux de la lignée $\mathrm{C}$, avec une proportion plus faible de fibres oxydo-glycolytiques, une proportion plus importante de fibres glycolytiques, une valeur plus forte du rapport $\mathrm{LDH} / \mathrm{CS}$ et une teneur plus faible en pigment. (C) Inra/Elsevier, Paris

porc / expérience de sélection / potentiel glycolytique / muscle / qualité de la viande

\section{INTRODUCTION}

Pig meat quality is a composite concept, and taking account of meat quality in pig breeding programmes is made possible only if appropriate selection criteria are defined. There is some advantage to using a selection criterion 
that can be measured on live animals, in terms of selection costs and efficiency. Before choosing such a criterion, it should be demonstrated that it is heritable enough and genetically related to the trait(s) to be improved. The in vivo measurement of muscle glycolytic potential [17] has been suggested as a possible selection criterion for improving technological meat quality, in particular the technological yield of cured-cooked ham processing, which is among the most important traits for the pork processing industry in France. It was shown by Le Roy et al. [19] that the in vivo measurement of muscle glycolytic potential (IVGP) is an efficient selection criterion in pig populations segregating for the major RN gene, known to strongly influence this trait [20]. It has also been established in a selection experiment [21] that IVGP can be reduced in a Large White population presumably free of the $\mathrm{RN}^{-}$allele. In the same selection experiment, a number of meat quality traits were measured in order to determine the genetic relationships between IVGP and meat quality traits and to assess the effects of selection for low IVGP on these traits. Results obtained in that respect are reported in the present article.

\section{MATERIALS AND METHODS}

\subsection{Animals}

Details on the selection experiment aiming at reducing muscle glycolytic potential in Large White pigs were given by Le Roy et al. [21]. One line (S) was selected for a low muscle glycogen content as assessed by in vivo glycolytic potential (IVGP) in the longissimus muscle, whereas a control line (C) was randomly bred. This experiment was carried out over six generations at the Inra experimental farm of Bourges-Avord. Both lines consisted of six to eight sires and 35 to 40 dams per generation, and each dam was expected to produce two litters. Selection was made among male and female offspring from first-parity litters. The present study deals with meat quality and muscle compositional traits measured on offspring from second-parity litters to study correlated responses to selection. Animals were reared as described by Le Roy et al. [21] and slaughtered when they reached $100 \mathrm{~kg}$ live weight. One animal per second-parity litter, either a gilt or a castrated male, was randomly chosen for an extensive protocol of measurements. In addition, two full-sibs of each animal submitted to this protocol (one gilt and one castrated male) were slaughtered and recorded for a smaller number of meat quality traits. The numbers of animals measured in each line are given in table $I$. All slaughtered animals were fasted for $16 \mathrm{~h}$ before they were transported for $2 \mathrm{~h}$ to a commercial abattoir. Then, animals were allowed to rest for an additional $18 \mathrm{~h}$ before they were killed by electrical stunning and immediate exsanguination. Pigs were reared and slaughtered in compliance with the current national regulations prevailing for commercial slaughtering and animal research experimentation.

\subsection{Measurements}

\subsubsection{Meat quality traits}

A number of meat quality traits were measured at $24 \mathrm{~h}$ post mortem on all slaughtered animals. Ultimate $\mathrm{pH}(\mathrm{pH} 24 \mathrm{~h})$ was measured directly on muscle 
Table I. Structure of the data set.

\begin{tabular}{lcc}
\hline Numbers & Selected line & Control line \\
\hline Sires & 48 & 55 \\
Litters & 207 & 190 \\
Slaughtered pigs* & $608(294)$ & $577(290)$ \\
'Extensive protocol' pigs & $232(109)$ & $222(112)$ \\
\hline
\end{tabular}

* The number of female pigs are given in parentheses.

using a combined glass electrode (Ingold, Mettler Toledo, Switzerland) and a portable pHmeter (CG818, Schott Gerät, Germany) for adductor femoris and longissimus muscles and, except for the animals submitted to the extensive protocol, for biceps femoris and gluteus superficialis muscles.

In the first three generations, reflectance was measured on biceps femoris and gluteus superficialis muscles with the reflectometer of Valin-David. From the fourth generation onwards, a Minolta Chromameter CR-300 was used on the same muscles to measure lightness ( $\mathrm{L}^{*}$ value). As reflectance and lightness are very closely correlated both phenotypically and genetically $[36,37], \mathrm{L}^{*}$ values were estimated from reflectance records for the first three generations using muscle-dependent equations. These equations were established using means and standard deviations estimated from the present data set, and assuming that the phenotypic correlation between reflectance and $\mathrm{L}^{*}$ was 0.91 for all muscles.

Water-holding capacity was measured by the 'filter paper imbibition time' method [6]. This method consists in measuring the time required for the complete wetting of a piece of filter paper (around $1 \mathrm{~cm}^{2}$ ) put on the freshly cut surface of the muscle. The time of observation is limited to $3 \mathrm{~min}$. Waterholding capacity was measured on the biceps femoris and gluteus superficialis muscles (except for the animals submitted to the extensive protocol for the latter muscle).

\subsubsection{Extensive protocol traits}

\subsubsection{On the slaughter day}

Thirty minutes after slaughter, a $2 \mathrm{~g}$ sample of longissimus muscle was taken from the last rib and homogenised in $18 \mathrm{~mL}$ of $5 \mathrm{mM}$ iodoacetate for $\mathrm{pH}$ measurement ( $\mathrm{pH} 30 \mathrm{~min}$ ). On three muscles (longissimus, semimembranosus and semispinalis capitis), differing by their metabolic and contractile properties $[15,23]$, a sample (approximately $1 \mathrm{~g}$ ) was taken and immediately frozen in liquid nitrogen and stored at $-80^{\circ} \mathrm{C}$ until the determination of lactate dehydrogenase (LDH) and citrate synthase (CS) activities [2, 34]. These enzymes were chosen as markers of the glycolytic and oxidative capacities of the muscle, respectively.

Within $1 \mathrm{~h}$ after slaughter, a sample was taken from the longissimus muscle at the last rib level. The sample was restrained on flat sticks to keep its initial length, and subsequently frozen in isopentane cooled by liquid nitrogen. The samples were stored at $-80^{\circ} \mathrm{C}$ until analysis at the Inra Pig Research 
Station (Saint-Gilles). Ten micrometre thick transverse serial sections were cut in a cryostat at $-20^{\circ} \mathrm{C}$ and stained for the actomyosin ATPase after acid preincubation at $\mathrm{pH}=4.35$ in order to identify type I, IIA and IIB fibres [5]. Type IIC fibres were not considered because very few of them can be observed at this stage of development [35]. A serial section was processed for succinate dehydrogenase [24] to identify oxidative (r) and non-oxidative (w) fibres. Fibres were classified as types I, IIA, IIBr and IIBw. Type I and IIA fibres are oxidative. Type IIA and IIBr fibres correspond to the $\alpha \mathrm{R}$ fibres described by Ashmore and Doerr [1], whereas type I and IIBw fibres correspond to $\beta \mathrm{R}$ and $\alpha \mathrm{W}$ fibres, respectively. Four fields containing 200-250 fibres each were randomly chosen to evaluate the percentage of each fibre type and the average cross-sectional area (CSA) of all fibres of the same type using a computerised image analysis system [18]. The relative area occupied by each fibre type was calculated from the corresponding percentages and mean CSA. The total number of fibres was approximated by the loin eye area/mean CSA ratio.

\subsubsection{On the day after slaughter}

At $24 \mathrm{~h}$ post mortem, $\mathrm{pH}$ was measured directly on semimembranosus and semispinalis capitis muscles. Reflectance (generations G1-G3) then lightness L* value (generations G4-G6) were measured on gluteus profundus and longissimus muscles, and $\mathrm{L}^{*}$ value was estimated for the first three generations as explained earlier.

A portion of the loin was taken at the level of the last rib, ice-chilled and transported to the Inra Meat Research Station (Theix) for the determination of longissimus muscle chemical composition. Samples were taken for the determination of dry matter $\left(105^{\circ} \mathrm{C}\right.$ for $\left.48 \mathrm{~h}\right)$, fat [11], haem pigment [13], hydroxyproline [3] and nitrogen contents [10].

One ham was sent to the Centre technique de la salaison, de la charcuterie et des conserves de viandes to be transformed into cured-cooked ham [14]. First, hams were deboned and trimmed. They were then injected with brine $10 \%$ of trimmed weight) and put in the brine for $70 \mathrm{~h}$. After dripping, they were put in a mould and cooked until core temperature reached $67^{\circ} \mathrm{C}$. Curing gain and cooking loss were defined as the following ratios: (weight of cured ham - weight of deboned, trimmed ham) / weight of deboned, trimmed ham and (weight of cured ham - weight of cooked ham) / weight of cured ham, respectively. Technological yield was the ratio of the weight of cooked ham to the weight of deboned, trimmed ham.

\subsection{Statistical analysis}

Preliminary least squares analyses were performed using the GLM procedure of SAS [29] in order to determine the fixed effects which should be taken into account in the following analyses.

Variance-covariance components were estimated using a restricted maximum likelihood (REML) procedure applied to a multiple-trait individual animal model. The model for all traits contained sex as a fixed effect and carcass weight as a covariate, with day of slaughter and additive breeding value included as random effects. Day of slaughter (136 levels, among which 38 levels 
for the extensive protocol) was considered as a random effect due to the small number of pigs recorded per day of slaughter. A random litter effect was first included in the model for the traits measured on all slaughtered animals but was removed in the final analysis because the litter component of variance was always zero. All the ancestors of the tested animals, up to the grandparents of the base population from which the control and selected lines were derived, were included in the pedigree file to establish the numerator relationship matrix of the animals.

The inclusion of all traits in a single analysis was not possible owing to computational limitations. The estimation of genetic parameters was performed in a series of two-trait analyses including the selection criterion (IVGP) and one other trait. These analyses were performed with version 3.2 of the VCE computer package, using a quasi-Newton algorithm with exact first derivatives to maximise the log likelihood [25]. Approximate standard errors of variance components and genetic parameters were obtained from the inverse of an approximation of the Hessian matrix when convergence was reached [30]. Coheritabilities of all traits with IVGP were calculated from REML-estimated parameters. Coheritability of one trait with IVGP is the genetic correlation between both traits multiplied by the square root of both heritabilities. Their standard errors were approximated from the standard errors of component parameters using the first-order term of a Taylor expansion.

Additive breeding values were estimated in two-trait analyses with a best linear unbiased predictor (BLUP) methodology applied to an individual animal model as previously described for the REML analysis. The REML-estimated genetic parameters were used in the model. The analyses were performed using the PEST computer package [12]. Mean breeding values were calculated per line for each generation. When averaging breeding values for a trait, only individuals having a record for that trait were taken into account. The genetic trend was estimated by the linear regression of the difference between the mean breeding values of both lines (selected and control) on the generation number. For simplification, the approximate variances for the annual $\mathrm{S}-\mathrm{C}$ differences were calculated for each trait with REML-estimated parameters, considering that animal breeding values were computed in univariate analyses [33]. Regression was constrained to pass through the origin because both lines were taken from the same base population, and each line difference was weighted by the inverse of its approximate sampling variance.

\section{RESULTS}

\subsection{Technological meat quality}

The means, phenotypic standard deviations, genetic parameters and genetic correlated responses to selection are given in table II. Heritability values of physicochemical traits ranged from 0.03 ( $\mathrm{L}^{*}$ gluteus profundus) to $0.39(\mathrm{pH} 24$ biceps femoris). Regarding the heritability values of ultimate $\mathrm{pH}$, three groups of muscles can be distinguished: one with a low heritability (semispinalis capitis), another with medium heritability values (gluteus superficialis, semimembranosus and longissimus) and the last group with the highest heritability values (biceps femoris and adductor femoris). For $\mathrm{L}^{*}$ value, heritability estimates 


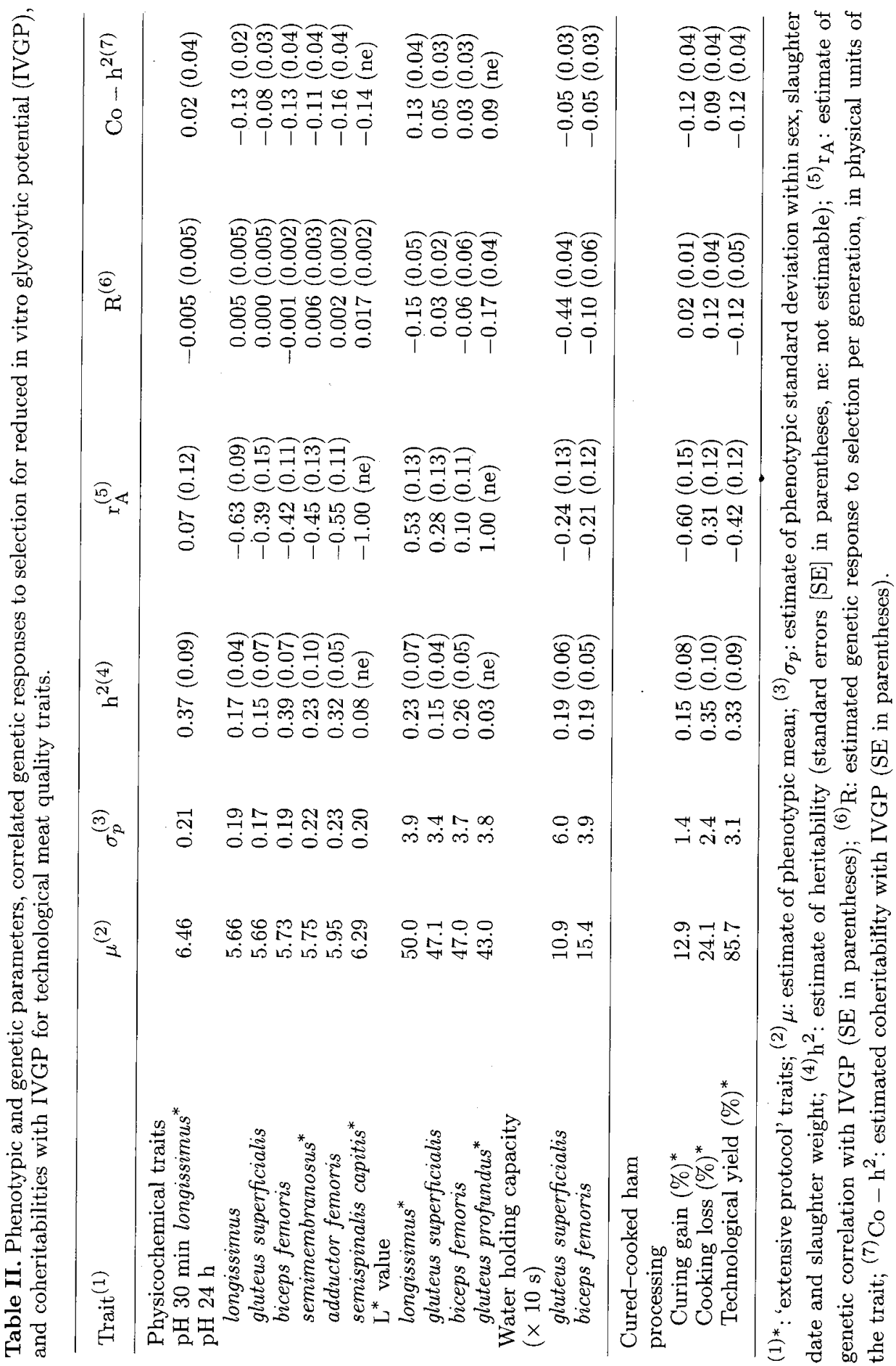


were of the same magnitude whatever the muscle, except for the gluteus profundus muscle, which showed a low heritability. The heritability values of cooking loss and technological yield were also in the medium range.

The genetic correlation of IVGP with $\mathrm{pH} 30$ min was markedly smaller than with $\mathrm{pH} 24 \mathrm{~h}$. The magnitude of the genetic correlation between IVGP and $\mathrm{L}^{*}$ was muscle dependent. As for $\mathrm{pH} 24 \mathrm{~h}$, the highest genetic correlation with IVGP was found for the reddest muscle (gluteus profundus), which also showed the lowest heritability value. Though genetic correlations with IVGP were significant, responses to selection for $\mathrm{pH} 24 \mathrm{~h}$ and $\mathrm{L}^{*}$ were generally limited. Ultimate $\mathrm{pH}$ increased only in the semispinalis capitis muscle and, to a lesser extent, in the semimembranosus muscle, whereas $\mathrm{L}^{*}$ value decreased in the gluteus profundus and longissimus muscles. Genetic correlations between water-holding capacity and IVGP were low for both biceps femoris and gluteus superficialis muscles, but water-holding capacity significantly decreased in the latter muscle in the S line. Genetic correlations of cooking loss and technological yield with IVGP significantly differed from zero and were in the medium range. However, for both traits, the sign of the significant correlated response to selection for low IVGP was not consistent with that of the corresponding genetic correlation.

\subsection{Muscle metabolism and chemical composition}

The estimated values of heritability for the enzyme activities differed from one muscle to another (table III). The heritability value for the LDH/CS ratio tended to increase with the oxidative type of the muscle. Estimates of heritability were medium to high for all myofibre characteristics. Whatever the fibre characteristic (percentage, cross-sectional area or relative area), the heritability values pertaining to the type I fibres were the highest. Heritability values were in the medium range for muscle compositional traits, except for nitrogen content (table $I V$ ).

The genetic correlations between metabolic characteristics and IVGP depended on the enzyme and the muscle considered. There was a medium and positive genetic correlation between IVGP and the LDH activity of the semimembranosus whereas no relationship was found with the LDH activity of the other two muscles. For CS activity, the value of the genetic correlation with IVGP decreased with the increase in the oxidative type of the muscle. The LDH/CS ratio of the longissimus and semispinalis capitis muscles showed a positive correlated response to selection for low IVGP. To a lesser extent, LDH activity was also affected by selection, but following a pattern depending on the muscle: no significant response in the longissimus and semimembranosus muscles and a significant increase in the semispinalis capitis muscle. For longissimus muscle chemical composition, the only significant genetic correlation was found between IVGP and haem pigment content, and, accordingly, there was a highly significant decrease of this content in the selected line. The other compositional traits were not genetically related to IVGP and were unaffected by selection. The zero heritability estimated for nitrogen content did not make it possible to estimate the genetic correlation between this trait and IVGP. 


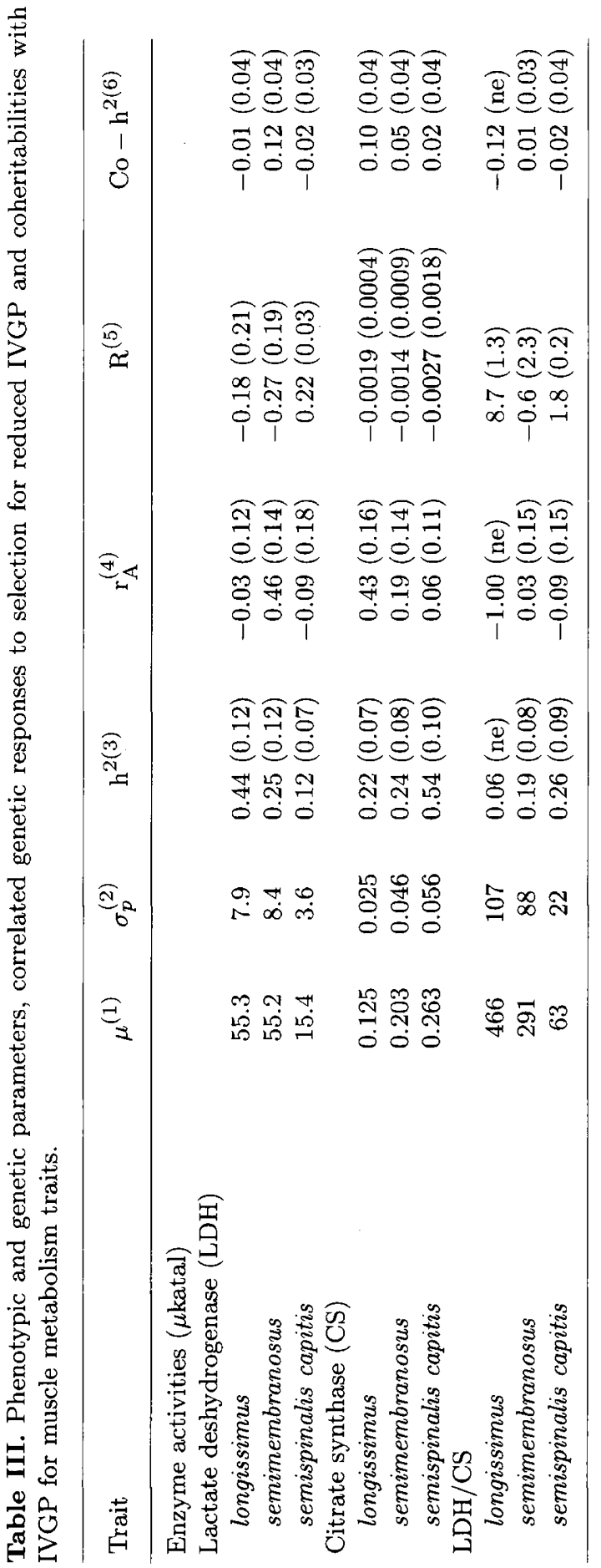




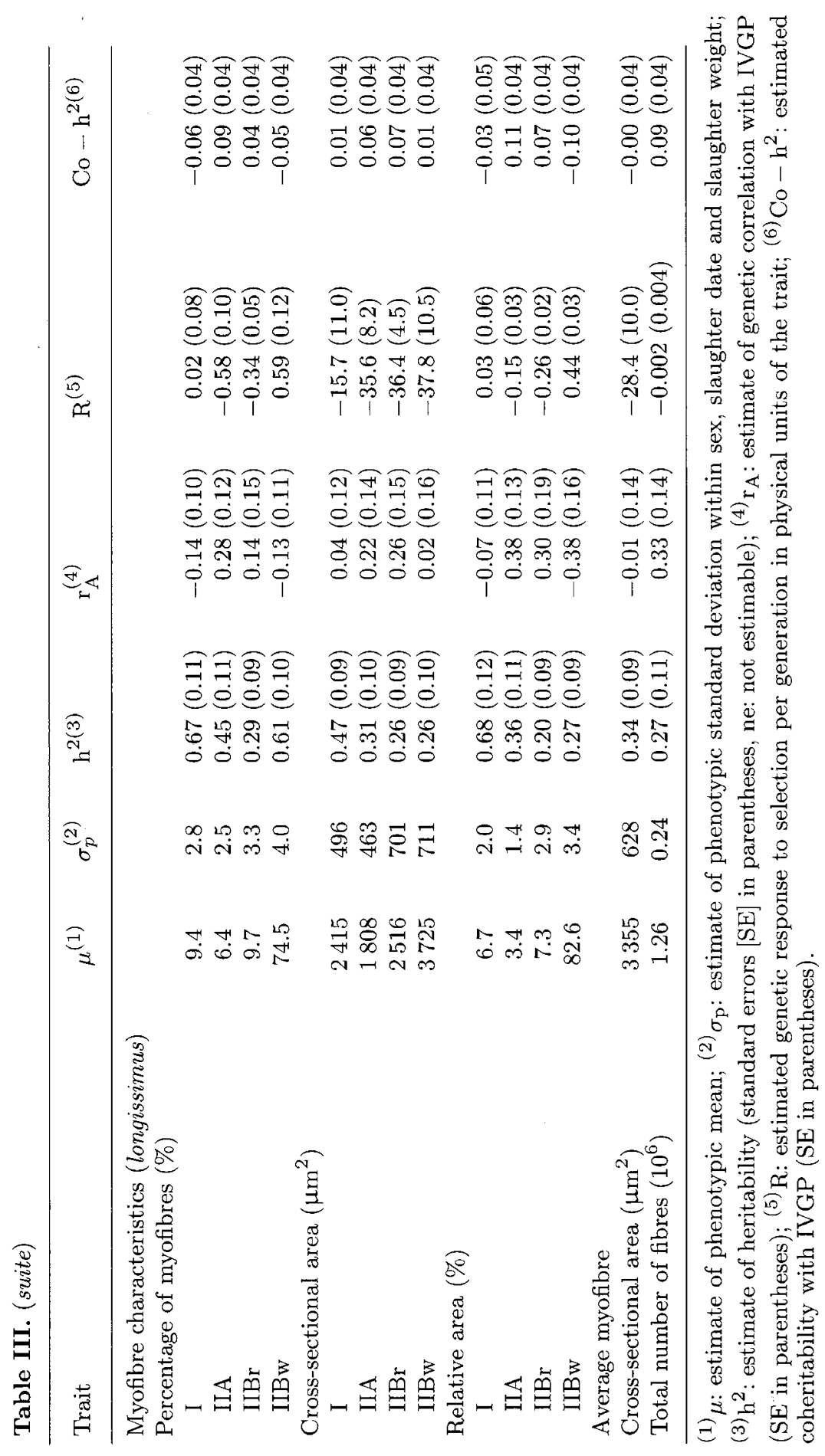


Table IV. Phenotypic and genetic parameters, correlated genetic responses to selection for reduced IVGP and coheritabilities with IVGP for chemical composition of the longissimus muscle.

\begin{tabular}{lcccccc}
\hline Trait & $\mu^{(1)}$ & $\sigma_{p}^{(2)}$ & $\mathrm{h}^{2(3)}$ & $\mathrm{r}_{\mathrm{A}}^{(4)}$ & $\mathrm{R}^{(5)}$ & $\mathrm{Co}-\mathrm{h}^{2(6)}$ \\
\hline $\begin{array}{l}\text { Dry matter (\%) } \\
\text { Haem pigment }\end{array}$ & 25.3 & 0.5 & $0.35(0.10)$ & $0.18(0.13)$ & $-0.03(0.01)$ & $0.05(0.04)$ \\
(mg/g) & 2.04 & 0.42 & $0.33(0.08)$ & $0.33(0.14)$ & $-0.036(0.004)$ & $0.09(0.04)$ \\
Fat (\%) & 1.34 & 0.33 & $0.44(0.09)$ & $0.03(0.13)$ & $-0.016(0.008)$ & $0.01(0.04)$ \\
Nitrogen (mg/g) & 34.9 & 1.7 & $0.00(\mathrm{ne})$ & $\mathrm{ne}$ & 0.00 & $0.0(\mathrm{ne})$ \\
$\begin{array}{l}\text { Hydroxyproline } \\
\text { (mg/g dry tissue) }\end{array}$ & 1.51 & 0.26 & $0.59(0.05)$ & $-0.05(0.09)$ & $0.024(0.012)$ & $-0.02(0.03)$ \\
\hline
\end{tabular}

${ }^{(1)} \mu$ : estimate of phenotypic mean; ${ }^{(2)} \sigma_{p}$ : estimate of phenotypic standard deviation within sex, slaughter date and slaughter weight; ${ }^{(3)} \mathrm{h}^{2}$ : estimate of heritability (standard errors [SE] in parentheses, ne: not estimable); ${ }^{(4)} \mathrm{r}_{\mathrm{A}}$ : estimate of genetic correlation with IVGP (SE in parentheses); ${ }^{(5)} \mathrm{R}$ : estimated genetic response to selection per generation in physical units of the trait; ${ }^{(6)} \mathrm{Co}-\mathrm{h}^{2}$ : estimated coheritability with IVGP (SE in parentheses).

\section{DISCUSSION}

\subsection{Heritabilities}

The heritability value for $\mathrm{pH} 30 \mathrm{~min}$ was higher than the average literature value of 0.16 [31]. Heritability values for $\mathrm{pH} 24 \mathrm{~h}$ reported by Sellier and Monin [32] tended to be similar (around 0.20) to the present estimates pertaining to the longissimus, semimembranosus and gluteus superficialis muscles, whereas the biceps femoris and adductor femoris muscles presented higher heritability values. Our heritability estimates differed from previous values reported by Bidanel et al. [4] in a French Large White population for ultimate $\mathrm{pH}$ of adductor femoris, semimembranosus and semispinalis capitis muscles $(0.22$, 0.17 and 0.22 , respectively). These authors found no muscle difference for heritability of $\mathrm{pH} 24 \mathrm{~h}$ whereas, in the present study, the adductor femoris muscle had a clearly higher heritability value than the semispinalis capitis muscle, the semimembranosus being intermediate. Our heritability estimates for $\mathrm{L}^{*}$ value and water-holding capacity were similar to those reported by Sellier and Monin [32] from the literature, except for the $\mathrm{L}^{*}$ value of the gluteus profundus muscle. The heritability value for technological yield of cured-cooked ham processing was similar to the average value of 0.27 reported from the literature [31].

Heritability values for muscle enzyme activities have scarcely been estimated in previous studies dealing with pigs. The only estimate found in the literature is a value of 0.46 for the heritability of $\mathrm{LDH}$ activity [38], but the muscle involved was not clearly specified. In other species, heritability values for LDH activity 
were of medium magnitude: 0.28 in cattle [28] and 0.26 in mice [22]. Results on isocitrate dehydrogenase activity in cattle [28] suggested that the heritability of muscle oxidative enzyme activities could depend on the metabolic type of the muscle, and this pattern was also found here for CS activity which was more heritable in 'red-type' than in 'white-type' muscles. Heritability values for myofibre percentages were much higher than the previous estimates $(0.14$ to 0.16 ) [7]. As fully discussed by Larzul et al. [16], heritability estimates of fibre percentages may depend on myofibre typing methods and classification used. Conversely, our heritability estimates for the myofibre cross-sectional areas were very similar to the values found by Dietl et al. [7].

Muscle chemical composition traits, except nitrogen content, had medium heritability values, which is in agreement with the literature [31]. The zero heritability found for nitrogen content was unexpected with regard to the literature [31] and the medium heritability of other muscle compositional traits found in the present study.

\subsection{Genetic correlations and responses to selection}

The rate of muscle $\mathrm{pH}$ fall was not genetically correlated with muscle glycogen content, as shown by the very low genetic correlation between $\mathrm{pH} 30 \mathrm{~min}$ and IVGP. Recently, Przybylski et al. [27] found no phenotypic relationship between IVGP and $\mathrm{pH}$ at $1 \mathrm{~h}$ post mortem. The closeness of the genetic correlations between IVGP and ultimate $\mathrm{pH}$ was lower than that of the genetic correlations previously found between IVGP and post mortem glycolytic potential [21], at least in the longissimus and semimembranosus muscles. The very high genetic correlation between IVGP and $\mathrm{pH} 24 \mathrm{~h}$ of semispinalis capitis muscle was unreliable owing to the low heritability value of the latter trait. In the $\mathrm{S}$ line, the increase in ultimate $\mathrm{pH}$ was small in all 'white' and 'intermediate' muscles, but was greater in the 'red' semispinalis capitis muscle. When considering the coheritabilities of $\mathrm{pH} 24 \mathrm{~h}$ with the selection criterion IVGP, ultimate $\mathrm{pH}$ should have increased in all muscles in response to selection for low IVGP. The genetic correlations and coheritabilities of water-holding capacity with IVGP were negative but fairly low for both studied muscles. However, water-holding capacity decreased, on average, in the $\mathrm{S}$ line, and the genetic trend was larger in the gluteus superficialis than in the biceps femoris, i.e. in the muscle showing the lowest average water-holding capacity and the largest phenotypic standard deviation. Genetic correlations between water-holding capacity and muscle glycogen content have not to our knowledge been estimated previously. Several studies showed that, phenotypically, water-holding capacity decreases when muscle glycogen content or glycolytic potential increases [17], which is in agreement with the genetic correlations found in the present study but not with the responses to selection. Given that selection for low IVGP was practised, a negative genetic correlation should imply a positive correlated response to selection.

The tendency to improved technological meat quality when decreasing muscle glycogen content was shown by the significant negative genetic correlations of IVGP with ultimate $\mathrm{pH}$ or technological yield. However, no significant genetic change could be found for the latter trait in the $\mathrm{S}$ line compared with the 
C line. Some explanations can be suggested for this discrepancy. The long fasting period and resting time at the abattoir could have flattened the differences between the two lines. That the response in ultimate $\mathrm{pH}$ depends on the muscle could be related to the non-linear relationship between muscle glycolytic potential at slaughter and ultimate $\mathrm{pH}[8,16,26]$. When glycogen content increases, ultimate $\mathrm{pH}$ decreases until glycogen content reaches a plateau value. Muscle glycogen content is generally high enough in 'white' muscles to reach this value. Only when this content is not high enough does ultimate $\mathrm{pH}$ increase when muscle glycolytic potential decreases. The decrease of muscle glycolytic potential in the 'white' longissimus muscle induced by selection [25] may not be large enough to increase ultimate $\mathrm{pH}$. In a 'slow-red' muscle such as semispinalis capitis, the glycogen content is generally not high enough to enable the $\mathrm{pH}$ to reach the plateau value, so that a slight decrease of glycolytic potential leads to an increase in ultimate $\mathrm{pH}$. The lack of significant response to selection in technological yield of cured-cooked ham processing is in agreement with the lack of response in ultimate $\mathrm{pH}$ in the 'white' muscles of the ham, which make up the most important part of this carcass joint. However, technological yield is known to be directly affected by ultimate $\mathrm{pH}$, but also by residual glycogen content of meat [9]. As there was no significant response in the selected line for the glycolytic potential of the semimembranosus ham muscle, the smoothed response to selection in the technological yield of cooked ham processing could also be related to the lack of line difference in residual glycogen content of ham muscles.

The present study showed that decreasing muscle glycogen content enhanced the glycolytic pathways of energetic metabolism in the longissimus muscle. This trend is exhibited both by myofibre type percentages, LDH/CS ratio and haem pigment content. This effect is in agreement with the known effects of the $\mathrm{RN}^{-}$ allele which increases glycolytic potential and decreases the proportion of whitetype myofibres in the same muscle [20]. Clearly, the relationships of metabolic and contractile fibre types with glycogen content deserve further investigation.

The absence of response in muscle protein content (assessed by nitrogen content) was unexpected. Indeed, it could be hypothesised that when glycogen content decreases, at least one of the other muscle compounds should exhibit an increased content. As previously observed in a population where the $\mathrm{RN}^{-}$allele was segregating, this allele increases GP and decreases protein content [20]. However, in the present study, protein content was not affected by downward selection on IVGP.

\section{CONCLUSION}

Downward selection on in vivo muscle glycolytic potential led to fairly limited correlated response in terms of meat quality. There was no important increase in ultimate $\mathrm{pH}$, except in the 'red-type' semispinalis capitis muscle, and no improvement was found in technological yield of cured-cooked ham processing. However, selection for reduced IVGP modified the energetic metabolism of the longissimus muscle toward a more glycolytic metabolism. The estimated genetic correlations of IVGP with meat quality traits were in the medium range, and thus, it can be concluded that improvement of technological meat quality is feasible through reducing muscle glycogen content. 


\section{ACKNOWLEDGEMENTS}

This work was part of the project 'Régulation du potentiel glycolytique du muscle chez le porc' and was supported by grants from the Inra-Agrobio programme initiated in 1990. Thanks are due to Jacques Mourot (Station de recherches porcines, SaintGilles) for the determination of intramuscular fat content, Pierre Vernin (Station de recherches sur la viande, Theix), Hervé Lagant (Station de génétique quantitative et appliquée, Jouy-en-Josas), and the staff of the pig experimental unit in Bourges-Avord for their technical assistance.

\section{REFERENCES}

[1] Ashmore C.R., Doerr L., Comparative aspects of muscle fiber types in different species, Exp. Neurol. 31 (1971) 408-418.

[2] Bass A., Brdiczka D., Eyer P., Hofer S., Pette D., Metabolic differentiation of distinct muscle types at the level of enzymatic organization, Eur. J. Biochem. 10 (1969) 198-206.

[3] Bergman I., Loxley R., Two improved and simplified methods for the spectrophotometric determination of hydroxyproline, Anal. Chem. 35 (1963) 1961-1965.

[4] Bidanel J.P., Ducos A., Guéblez R., Labroue F., Genetic parameters of backfat thickness, age at $100 \mathrm{~kg}$ and ultimate $\mathrm{pH}$ in on-farm tested French Landrace and Large White pigs, Livest. Prod. Sci. 40 (1994) 291-301.

[5] Brooke M.H., Kaiser K.K., Muscle fiber types: How many and what kind?, Arch. Neurol. 23 (1970) 369-379.

[6] Charpentier J., Monin G., Ollivier L., Correlations between carcass characteristics and meat quality in Large White pigs, in: Proceedings of the 2nd International Symposium on Condition and Meat Quality of Pigs, Pudoc, Wageningen, 1971, pp. 255-260.

[7] Dietl G., Groeneveld E., Fiedler I., Genetic parameters of muscle structure traits in pigs, in: Proceedings of the 44th EAAP Ann. Meeting, Aarhus, Denmark, 1993.

[8] Fernandez X., Guéblez R., Relationship between lactate and glycogen contents and $\mathrm{pH}$ values in post mortem Longissimus muscle of the pig, in: Proceedings of the 38th Int. Congress of Meat Sci. and Technol., Clermont-Ferrand, France, 1992, pp. 355-358.

[9] Fernandez X., Lefaucheur L., Guéblez R., Monin G., Paris ham processing: technological yield as affected by residual glycogen content of muscle, Meat. Sci. 29 (1991) 121-128.

[10] Ferrari A., Nitrogen determination by a continuous digestion and analysis system, Ann. N.Y. Acad. Sci. 87 (1960) 792-800.

[11] Folch J., Lee M., Sloane Stanley G.H., A simple method for the isolation and purification of totals lipids from animal tissues, J. Biol. Chem. 226 (1957) 497.

[12] Groeneveld E., Kovac M., A generalized computing procedure for setting up and solving mixed linear models, J. Dairy Sci. 73 (1990) 513-531.

[13] Hornsey H.C., The color of cured-cooked pork. I. Estimation of the nitricoxide-haem pigments, J. Sci. Food. Agric. 7 (1956) 534-540.

[14] Jacquet B., Sellier P., Runavot J.P., Brault D., Houix Y., Perrocheau C., Gogué J., Boulard J., Prédiction du rendement technologique de la fabrication du «jambon de Paris » à l'aide de mesures prises à l'abattoir, in : $16^{\text {es }}$ Journées de la recherche porcine en France, Paris, 1-3 février 1984, Institut technique du porc, Paris, 1984, pp. 49-58. 
[15] Laborde D., Talmant A., Monin G., Activités enzymatiques métaboliques et contractiles de 30 muscles du Porc. Relations avec le pH ultime atteint après la mort, Reprod. Nutr. Dév. 25 (1985) 619-628.

[16] Larzul C., Lefaucheur L., Ecolan P., Gogué J., Talmant A., Vernin P., Sellier P., Le Roy P., Monin G., Phenotypic and genetic parameters of longissimus muscle fiber characteristics in Large White pigs, J. Anim. Sci. 75 (1997) 3125-3136.

[17] Larzul C., Le Roy P., Monin G., Sellier P., Variabilité génétique du potentiel glycolytique du muscle chez le porc, Inra Prod. Anim. 11 (1998) 183-197.

[18] Lefaucheur L., Missohou A., Ecolan P., Monin G., Bonneau M., Performance, plasma hormones, histochemical and biochemical muscle traits, and meat quality of pigs administered exogenous somatotropin between 30 or 60 kilograms and 100 kilograms body weight, J. Anim. Sci. 70 (1992) 3401-3411.

[19] Le Roy P., Przybylski W., Burlot T., Bazin C., Lagant H., Monin G., Étude des relations entre le potentiel glycolytique du muscle et les caractères de production dans les lignées Laconie et Penshire, in : $26^{\text {es }}$ Journées de la recherche porcine en France, Paris, 1-3 février 1994, Institut technique du porc, Paris, 1994, pp. 311-314.

[20] Le Roy P., Monin G., Elsen J.M., Caritez J.C., Talmant A., Lebret B., Lefaucheur L., Mourot J., Juin H., Sellier P., Effect of the RN genotype on growth and carcass traits in pigs, in: Van Arendonk J.A.M. (Ed.), Book Abstr. of the 47th EAAP Ann. Meeting, Wageningen Pers, Wageningen, Netherlands, 1996.

[21] Le Roy P., Larzul C., Gogué J., Talmant A., Monin G., Sellier P., Selection for reduced muscle glycolytic potential in Large White pigs. I. Direct responses, Genet. Sel. Evol. 30 (1998) 469-480.

[22] Major F., Tawfik E.S., Enzymaktivitäten und genetische Polymorphismen bei der Maus als Modelltier unter dem Einfluss der Selektion auf Belastbarkeit und Proteinansatz. V. Heritabilitäten und Beziehungen zwischen Enzymaktivitäten im Blutplasma, Herz, Muskel und Leber, Z. Tierzucht. Zuchtgsbiol. 98 (1980) 21-28.

[23] Monin G., Mejenes-Quijano A., Talmant A., Sellier P., Influence of breed and muscle metabolic type on muscle glycolytic potential and meat $\mathrm{pH}$ in pigs, Meat Sci. 20 (1987) 149-158.

[24] Nachlas N.M., Tsou K.G., DeChang C.S., Seligman A.M., Cyto-chemical demonstration of dehydrogenase by the use of a new p-nitrophenol-substituted detetrazole, J. Histochem. Cytochem. 5 (1957) 420-436.

[25] Neumaier A., Groeneveld E., Restricted maximum likelihood estimation of covariances in sparse linear models, Genet. Sel. Evol. 30 (1998) 3-26.

[26] Przybylski W., Vernin P., Monin G., Relationship between glycolytic potential and ultimate $\mathrm{pH}$ in bovine, porcine and ovine muscles, J. Muscle Foods 5 (1994) 245255.

[27] Przybylski W., Kocwin-Podsiadla M., Kaczorek S., Krzecio E., Naveau J., Tyszkiewicz I., Glycolytic potential and meat quality in crossbred pigs of different genetic groups, in: Proceedings of the 41st Int. Congress Meat Sci. and Technol., San Antonio, TX, USA, 1995, pp. 104-105.

[28] Renand G., Jurie C., Robelin J., Picard B., Geay Y., Ménissier F., Genetic variability of muscle biological characteristics of young Limousin bulls, Genet. Sel. Evol. 27 (1995) 287-298.

[29] SAS $^{\circledR}$, SAS $^{\circledR}$ Users Guide: Statistics (Version 5 Ed.). SAS ${ }^{\circledR}$ Institute, Inc., Cary, NC, USA, 1985.

[30] Searle S.R., Casella G., McCulloch C.E., Variance Components, John Wiley \& Sons, New York, NY, 1992.

[31] Sellier P., Genetics of meat and carcass traits, in: Rothschild M.F., Ruvinsky A. (Eds.), Genetics of the Pig, CAB International, Wallingford, Oxon, UK, 1998, pp. $463-510$. 
[32] Sellier P., Monin G., Genetics of pig meat quality, a review, J. Muscle Foods 5 (1994) 187-219.

[33] Sorensen D.A., Kennedy B.W., Analysis of selection experiments using mixed model methodology, J. Anim. Sci. 63 (1986) 245-258

[34] Srere P.A., Citrate synthase, in: Bourne G.H. (Ed.), Methods of Enzymatic Analysis, 2nd ed., Academic Press, New York, 1969, pp. 443-444.

[35] Suzuki A., Cassens R.G., A histochemical study of myofiber types in muscle of the growing pig, J. Anim. Sci. 51 (1980) 1449-1461.

[36] Tribout T., Garreau H., Bidanel J.P., Paramètres génétiques de quelques caractères de qualité de la viande dans les races porcines Large White et Landrace français, in : $28^{\mathrm{es}}$ Journées de la recherche porcine en France, Paris, 30 janvier-1 février 1996, Institut technique du porc, Paris, 1996, pp. 31-38.

[37] Warriss P.D., Brown S.N., The relationship between reflectance (EEL value) and colour $\left(\mathrm{L}^{*}\right)$ in pork loins, Anim. Sci. 61 (1995) 145-147.

[38] Weniger J.H., Steinhauf D., Glodek P., Meat quality as a selection criterion in the pig, Z. Tierzuchtg. Zuchtgsbiol. 87 (1970) 230-239. 